\title{
Analysis of working conditions focusing on biological risk: firefighters in Campo Grande, MS, Brazil
}

\author{
Luciana Contrera-Moreno, ${ }^{\mathrm{a},}$, Sonia Maria Oliveira de Andrade a , Ana Rita Coimbra Motta-Castro a , \\ Alexandra Maria Almeida Carvalho Pinto ${ }^{b}$, Frederico Reis Pouso Salas ${ }^{c}$ and Alcione Cavalheiros Faro \\ Stief $^{\text {a }}$ \\ ${ }^{a}$ Center for Biological and Health Sciences, Federal University of Mato Grosso do Sul, Cidade Universitária s/n, \\ 79070-900, Campo Grande - MS, Brazil. \\ ${ }^{\mathrm{b}}$ Faculty of Medicine, Federal University of Mato Grosso do Sul, Cidade Universitária s/n, 79070-900, Campo \\ Grande-MS, Brazil. \\ ${ }^{\mathrm{c}}$ Metropolitan Fire Command, Fire Brigade of Mato Grosso do Sul, Sete de setembro Street n. 408, 79080-790, \\ Campo Grande-MS, Brazil.
}

\begin{abstract}
Firefighters are exposed to a wide range of risks, among them, biological risk. The objective was to analyze working conditions of firefighters in the city of Campo Grande, MS, Brazil, focusing on risk conditions of exposure to biological material. Three hundred and seven (307) firefighters were interviewed for data collection and observed for ergonomic job analysis (AET). Results: $63.5 \%$ of the firefighters suffered some kind of job related accident with blood or body fluids. Statistically significant association was found between having suffered accidents at work and incomplete use of personal protective equipment (PPE). About AET regarding the biological risks, $57.1 \%$ of all patients had blood or secretions, which corresponds in average to $16.0 \%$ of the total work time, based on a working day of $24 \mathrm{~h}$. Besides biological risks, other stressing factors were identified: emergency and complexity of decision, high responsibility regarding patients and environment, and conflicts. Health promotion and accident prevention actions must be emphasized as measures to minimize these risks.
\end{abstract}

Keywords: Ergonomics, Personal Protective Equipment (PEE),blood, firemen, biological risks.

\section{Introduction}

Occupational transmission of hepatitis $\mathrm{B}, \mathrm{C}$ and HIV in military Personnel is a fact that has drawn the attention of many researchers ${ }^{[2,3]}$. Firefighters, due to the nature of their activities, also are at high risk of acquiring these infections ${ }^{[5,6,8]}$. In Campo Grande MS, Brazil, most of the events attended by firefighters are related to the rescue of victims of traffic accidents and transportation of medical and psychiatric emergencies. In addition, firefighters are exposed to building and forest fires, hazardous material spills (contamination), crimes and public disturbances, natural and human caused disasters ${ }^{[1]}$.

Therefore, the objective was to analyze the working conditions of firefighters in the city of Campo Grande, MS, focusing on the risk conditions of exposure to biological material.

\section{Methods}

A total of 307 firefighters were interviewed with questions about sociodemographic aspects and workrelated accidents with blood and body fluids. The

\footnotetext{
*Corresponding author. Luciana Contrera-Moreno, Tel.:+55 673345 7353. E-mail: 1.contrera@ufms.br $1051-9815 / 12 / \$ 27.50$ C 2012 - IOS Press and the authors. All rights reserved
} 
ergonomic job analysis (AET) in the rescue car was made between August and November of 2010, using the instrument of Rohmert and Landau ${ }^{[11]}$. The firefighters work in rotating shift schedule, 24 hours of work (from 07:30 to 08:00 hours the next day) followed by 72 hours (three days) of rest. They were followed and observed during the 24 hours of continuous work, during 3 days, totaling 72 hours of observation. Descriptive data analysis and statistical tests were performed, occupational accident was the dependent variable, sociodemographic and work data were the independent variables, Epi Info 3.4.1 was used. The AET was analyzed considering duration, frequency and relevance of the items related to tools, resources, environment, tasks and demands of the work.

\section{Results}

Average age of study participants was 36.4 years $(\mathrm{SD} \pm 6.5), 89.9 \%$ male, $75.2 \%$ had completed high school, 91.2\% were soldiers and $8.8 \%$ officers. $63.5 \%$ of the firefighters participants had suffered some kind of work accident with blood and body fluids. Statistically significant association was found between having suffered accidents at work and incomplete use of personal protective equipment (PPE) $(p=0.0043)$. Considering the AET, the most signifi- cant results regarding duration, frequency and relevance are summarized in figure 1. Regarding the biological risk, $57.1 \%$ of all patients had blood and secretions, which corresponds in average to $16.0 \%$ of the total work time, based on a working day of $24 \mathrm{~h}$. Concerning the use of PPE, if needed, examination gloves were used in $97.1 \%$ of the occurrences. Mask and protection goggles were not used in $5.7 \%$ of the emergences that they judged necessary to use. When cleaning and disinfecting materials, it was observed the use of examination gloves, which are inadequate because they are short, allowing contact with water and secretions.

Considering workload, it was observed that they work in average 25 hours shift, $68.2 \%$ of the time working (in the street average of 10.25 hours) or in the headquarters (average of 6.40 hours). Average rest time was 7.55 hours, including meals, sleep time and rest, which was interrupted in average 13 times during the shift.

Considering the type of occurrence, $48.5 \%$ was attending victims of traffic accidents, followed by medical emergencies $(22.8 \%)$, prank calls $(14.2 \%)$, specialized transportation $(5.7 \%)$, fires $(2.8 \%)$, victims of violence $(2.8 \%)$ and disasters prevention $(2.8 \%)$.

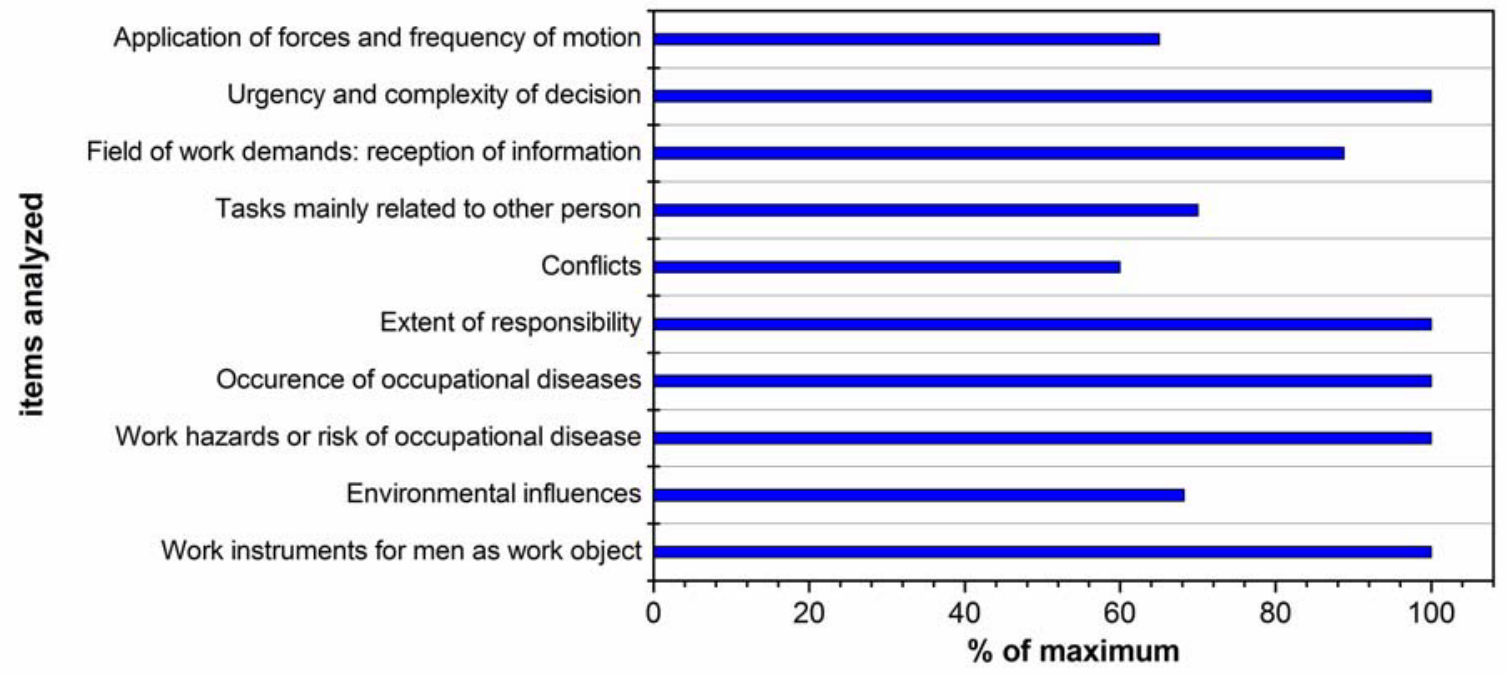

Fig. 1 Description of the most significant and frequent items in an ergonomic analysis of work of firefighters. Campo Grande, MS, Brazil 


\section{Discussion}

It was possible to assess with this study that the occurrence of work-related accidents is high and most of them are related to the misuse or non-use of personal protective equipment. It was observed that firefighters use PPE properly during most of the occurrences, however, when cleaning and disinfecting equipments and the rescue car, PPE is not used as needed, leaving the worker exposed to biological risks while performing these activities, this fact was also reported by Florêncio et. al. ${ }^{[10]}$ The use of masks and protection goggles during these procedures are also necessary because of the possibility of splashes on mucous membranes, and avoids risks of contamination from infectious disease in the work ${ }^{[7]}$. Another fact perceived with this work is that the majority of the occurrences involve attending bleeding victims, reinforcing the need of self-protection and immunization against Hepatitis $\mathrm{B}^{[4]}$.

Prank calls, $14.2 \%$ of the occurrences, are also another factor extremely stressing, because they interrupts sleep, generating stress and disgust. The fact that sleep is often interrupted, since the characteristic of the job do not allow resting periods, making the 24 hours shift very tiring, and causing fatigue. In one study with Japanese firefighters working 24 hours, the authors concluded that inadequate nap-time may affect their mental health ${ }^{[12]}$. It is also known that night jobs interfere with the circadian rhythm, causing severe and persistent sleep disorders, eating problems and impaired social life ${ }^{99}$.

It was observed long working hours (25 hours), where firefighters are exposed to biological risks, and also to a variety of risks associated to stressors such as use of physical strength, mental and emotional demand caused by the accidents they rescue, urgency and complexity of decisions, extent of responsibility (with patients and environment) and conflicts. Conflicts in the work environment, along with the variance in the workload, social support from a supervisor, role conflict and ambiguity and low self-esteem were significantly related to depressive symptoms and or job dissatisfaction in Japanese firefighters ${ }^{[12]}$.

Considering all the risks that firefighters are exposed, actions to improve working conditions and awareness regarding biological risk and correct use of PPE for all the firefighters activities should be considered because these professionals do an essential work for the entire society.

\section{Financial support}

This study was supported by the Fundação de Apoio ao Desenvolvimento do Ensino, Ciência e Tecnologia do Estado de Mato Grosso do Sul (Fundect/MS).

\section{References}

[1] A.A. Reichard and L.L.Jackson, Occupational Injuries among emergency responders, American Journal of Industrial Medicine 53(2010), 1-11.

[2] A. Chacaltana and J. Espinoza, Seroprevalence of the infection and risk factors of hepatitis $\mathrm{B}$ and $\mathrm{C}$ healthy military personnel. Revista de Gastroenterologia del Perú 28(2008),21725.

[3] A.E Brown, D.A Ross, A.J.H Simpson, R.S. Erskine, G. Murphy, J.V. Parry and O.N. Gill, Prevalence of markers for HIV, hepatitis B and Hepatitis C infection in UK military recruits, Epidemiology and Infection 139(2011),1166-1171.

[4] A.J. Roome, J.W. Stephen, M.L Cartter and J.L. Hadler, Hepatitis B vaccine responsiveness in Connecticut Public Safety Personnel. The journal of the American Medical Associatian 270(1993),2931-2934.

[5] B.A. Crosse, C. Teale and E.M. Lees, Hepatitis B markers in west yorkshire firemen Epidemiology and Infection 103(1989),383-385.

[6] B.A. Woodruff ,L.A. Moyer LA, K.M. O'Rourke and H.S. Margolis. Blood exposure and the risk of hepatitis B virus infection in firefighters, Journal of Occupational Medicine 35(1993), 1048-1054.

[7] C.D.C. Center for Disease Control and Prevention, Updated U.S. Public Health service Guidelines forthe Management of Occupational Exposures to HBV, HCV, and HIV and Recommendations for Postexposure Prophylaxis, Morbidity and Mortality Weekly Report 50(2001),1-54.

[8] F.M. Averhoff, L.A. Moyer, B.A. Woodruff, A.M. Deladisma, J. Nunnery, M.J. Alter and H.S. Margolis, Occupational exposures and risk of hepatitis B virus infection among public safety workers, Journal of Occupational and Environmental Medicine 44(2002),591-596.

[9] G. Costa, Saúde e trabalho em turnos e noturno, in: Trabalho em turnos e noturno na sociedade 24 horas, F.M. Fischer, C.R.C. Moreno and L. Rotenberg, Ed., Atheneu, São Paulo, 2003, pp. 65-76.

[10] V.B. Florêncio, C.A. Rodrigues, M.S. Pereira and A.C.S. Souza, Adesão às precauções padrão entre os 48 profissionais da equipe de resgate pré-hospitalar do Corpo de Bombeiros de Goiás, Revista Eletrônica de Enfermagem 5(2003),43-48.

[11] W. Rohmert and K. Landau, A new technique for job analysis, ed., Taylor \& Francis, London/ New York, 1983.

[12] T.U. Saijo and Y. Hashimoto, Twenty-four-hours shift work, depressive symptoms, and job dissatisfaction among Japanese firefighters, American Journal of Industrial Medicine 51(2008),380-391. 